İnceleme Makalesi - Review Article

\title{
Özel Sağlık Hizmet Sunucularında Çalışan Hekimlerin Sigortalılığı ${ }^{1}$
}

\section{Social Insurance Status of Doctors Working in Private Health Service Providers}

\author{
Özkan BILGiLí* \\ (iD) 0000-0002-1700-1427
}

Sosyal Güvenlik Dergisi / Journal of Social Security

Cilt: 11 Say1: 1 Y1l: 2021 / Volume: 11 Issue: 1 Year: 2021

Sayfa Aralığı: 33-54 / Pages: 33-54

DOI: $10.32331 /$ sgd.952536

\section{ÖZ}

Özel sağlık hizmet sunucuları bünyesinde çalışan hekimlerin sigortalı olmaları gerektiği açıktır. Ancak burada üzerinde durulması gereken hangi statüde sigortalı sayılacaklarıdır. Şu şekilde de sorabiliriz: Özel sağlık hizmet sunucularında çalışan hekimler 4/a statüsünde mi yoksa 4/b statüsünde mi sigortalı sayılır? Hekimlerin çalıştıkları özel sağlık hizmet sunucuları ile aralarındaki sözleşmenin niteliği sigortalılık statülerini de belirlemektedir. Şirket ortağı olan veya mesleğini serbest olarak icra eden hekimler ile tıpta uzmanlık mevzuatına göre uzman olan kişiler, özel hukuk kişileri ve/veya vakıf üniversitelerine ait sağlık kurum ve kuruluşları bünyesinde hizmet alım sözleşmesi yapmaksızın ya da iş (hizmet) sözleşmesi ile çalışmaları halinde 4/a statüsünde sigortalı sayılacaklardır. Öte yandan, şirket ortağı olan veya mesleğini serbest olarak icra eden hekimler ile tıpta uzmanlık mevzuatına göre uzman olan kișilerin, hizmet alım sözleșmesi ile özel hukuk kişileri ve/veya vakıf üniversitelerine ait sağlık kurum ve kuruluşları bünyesinde hizmet vermeleri halinde, hizmet alım sözleşmelerinde aksine bir hüküm bulunmadığı sürece $4 / \mathrm{b}$ kapsamında sigortalı sayılacaklardır. Özel sağlık hizmet sunucularında hizmet alım sözleşmesine dayalı olarak çalışan hekimlerin $4 / \mathrm{b}$ statüsünde sigortalı sayılmaları durumunda sigorta primlerini kendileri ödeyecektir. Ancak bunlar hakkında hastalık sigortası hükümleri uygulanmayacaktır. Belirtilen şekilde $4 /$ b kapsamında sigortalı sayılan hekimlerden şirket ortağ hakkında ise analı sigortası hükümleri uygulanmayacak, diğer hekimler hakkında ise uygulanacaktır.

Anahtar Sözcükler: Sağlık hizmet sunucusu, hekim, hizmet akdi, sigortalılık, hizmet alım sözleşmesi

\section{ABSTRACT}

It is obvious that doctors working within private health service providers should be insured. However, the point is that under which status they will be an insurance holder. We can ask this as follows: Are the doctors working in private health service providers deemed to be insurance holders under $4 / \mathrm{a}$ or $4 / \mathrm{b}$ status? The nature of contract between the doctor and the private health service provider where they work also determines their insurance status. Doctors who are partners of company or are self-employed and specialists according to legislation of specialty in medicine will be deemed to be insurance holders under 4/a status without making a service procurement agreement within health institutions and organizations belonged to private entities and/or foundation universities or by working with labour contract. On the other hand, in case the doctors who are partners of company or are selfemployed and specialists according to legislation of specialty in medicine serve within health institutions and organizations belonged to private entities and/or foundation universities with labour contract, they will be deemed to be insurance holders under $4 / b$ status unless there is a contrary provision in their service purchase agreement. In the event that the doctors working in private health service providers based on the service purchase agreement are deemed to be insurance holders under 4/b status, they will pay their insurance premiums on their own. However, provisions of disease insurance will not be applied for them. For the doctors who are insurance holders under $4 / b$ status in the mentioned way who are partners of company, provisions of maternity insurance will not be applied but these will be applied for other doctors..

Keywords: Health service provider, doctor, labour contract, insurance, service purchase contract

Önerilen atıf şekli: Bilgili, Ö. (2021). Özel Sağlık Hizmet Sunucularında Çalışan Hekimlerin Sigortalılığı. Sosyal Güvenlik Dergisi (Journal of Social Security). 11(1). 33-54

• Geliş Tarihi/Received: 01/03/2021 • Güncelleme Tarihi/Revised: 26/05/2021 • Kabul Tarihi/Accepted: 14/06/2021

\footnotetext{
${ }^{1}$ Bu makale, 06-08/11/2020 tarihlerinde düzenlenen 13. Uluslararası Güncel Araştırmalarla Sosyal Bilimler Kongresinde sunulan aynı başlıklı tebliğin gözden geçirilerek genişletilmiş halidir.

* Doç. Dr., İzmir Demokrasi Üniversitesi, İktisadi ve İdari Bilimler Fakültesi,

İnsan Kaynakları Yönetimi Bölümü, ozkan.bilgili@idu.edu.tr
} 


\section{GİRIș}

Kimlerin hangi statüde sosyal sigortalı (sigortalı) sayılacakları 5510 sayılı Sosyal Sigortalar ve Genel Sağlık Sigortası Kanunu'nun² ${ }^{2}$.maddesinde düzenlenmiştir. Buna göre, hizmet akdi ile bir ya da birkaç işveren tarafından çalıştırılanlar 4/a statüsünde, kendi adına ve hesabına bağımsız olarak çalışanlar 4/b statüsünde, kamu idarelerinde memur ve diğer kamu görevlisi olarak çalışanlar ise 4/c statüsünde sigortalı sayılmıştır (Güzel, Okur ve Caniklioğlu, 2020: 79-108; Tuncay ve Ekmekçi, 2019: 301-329; Sözer, 2019: 69-95). Buradan hareketle özel sağlık hizmet sunucularında hizmet veren tüm hekimlerin de "hizmet akdi" ile çalıştıkları varsayımı altında 4/a statüsünde sigortalı oldukları söylenebilir. Ancak, bu varsayım her zaman geçerli olmayabilir; özel sağlık hizmet sunucularında çalışan hekimler 4/b statüsünde de sigortalı olabilir. Dahası 4/b statüsünde sigortalılık asıl, 4/a statüsünde sigortalılık istisna bir hal de alabilir.

Gerçekten de, 6645 sayılı Kanun'un ile 5510 sayılı Kanuna ilave edilen ek 10.madde uyarınca, 23/04/2015 tarihinden geçerli olmak üzere, özel sağlık hizmet sunucularında çalışan hekimlerin 4/b kapsamında sigortalı olmalarının yolu açılmıştır. Kanun hükmüne göre, "Şirket ortağ l olan veya mesleğini serbest olarak icra eden hekimler ile tıpta uzmanlı mevzuatına göre uzman olan kişiler, özel hukuk kişileri ve/veya vakıf üniversitelerine ait sağlık kurum ve kuruluşları bünyesinde hizmet vermeleri hâlinde sözleşmelerinde aksine bir hüküm bulunmadıkça bu Kanunun 4 üncü maddesinin birinci fikrasının (b) bendi kapsamında sigortalı sayllır. Ancak, bu maddenin yayımı tarihinden önce 4 üncü maddenin birinci fikrasının (a) bendi kapsamında sigortalı olarak çalışılan sürelere ilişkin haklar saklıdır." (5510/Ek $10.2 \mathrm{md})$.

Özel sağlık hizmet sunucularının yardımcı işlerini dış kaynaktan temin etmeleri öteden beri yaygın bir uygulamayken, artık esas faaliyet konularına giren muayene, teşhis ve tedavi hizmetlerini de diş kaynak kullanarak gerçekleştirdikleri görülmektedir. Bu kapsamda faaliyet gösteren hekimlerden alınan hizmetin niteliği fatura düzenlenerek yapıldığ 1 için bu durum "hekimlik işgücü” hizmet alımı şeklindedir. Hekimlerin sunmuş oldukları faaliyetlerden dolayı fatura düzenleyebilmeleri için herhangi bir sağlık kuruluşuna hizmet akdi ile bağımlı olarak çalışmaksızın kendi nam ve hesaplarına ya serbest meslek faaliyeti yapmaları ya da herhangi bir şirket ortağı olmaları gerekmektedir (Bozdemir, 2018).

Böylece aynı özel sağlık hizmet sunucusunda fiilen benzer işe yapan hekimlerin bir kısmı 4/a bir kısmı da 4/b statüsünde sigortalı olabilecektir. Belki de çalışan tüm hekimler 4/b statüsünde sigortalı olacaktır. $\mathrm{Bu}$ ayrımın ise hekimlerin sosyal sigorta haklarında farklılaşmalara neden olacağını söyleyebiliriz.

Esasen benzer bir yaklaşıma kamu sağlık kurumlarında da rastlamak mümkündür. 657 sayılı Devlet Memurları Kanunu'nun ${ }^{3}$ 36.maddesinin “III- Sağlık Hizmetleri ve Yardımcı Sağlık Hizmetleri Sınıfı" başlıklı bendine 10/07/2003 tarihli ve 4924 say1lı Kanun'un 11.maddesi ile, "Bu sinıfa dahil personel tarafindan yerine getirilmesi gereken hizmetler, lüzumu halinde bedeli döner sermaye gelirlerinden ödenmek kaydıyla, Bakanlıkça (Săglık Bakanlı̆̆l) tespit edilecek esas ve usullere göre hizmet satın alınması yoluyla gördürülebilir." hükmü eklenmiştir. Anayasa Mahkemesi sözkonusu düzenlemenin Anayasaya aykırı olmadığına karar vermiş ve iptal talebini reddetmiştir ${ }^{4}$. Böylece kamu sağlık kurum ve kuruluşlarında “ihale ile sağlık personeli istihdamının” yolu açılmıştır (Bilgili, 2009: 417-424).

\footnotetext{
${ }^{2}$ 16/06/2006-26200 RG.

${ }^{3}$ 23/07/1965-12056 RG.

${ }^{4}$ Anayasa Mahkemesi, 22.11.2007, E:2004/114, K:2007/85. 24/12/2007-26736 RG.
} 
Özel Sağlık Hizmet Sunucularında Çalışan Hekimlerin Sigortalılığ1

Çalışmamızda özel sağlık hizmet sunucularında çalıştırılan hekimlerin sosyal sigorta nitelikleri, buna bağlı sosyal sigorta yardımları ile işsizlik sigortasına tabi olup olmadıkları ve sigorta vakalarında özel sağlık hizmet sunucularının sorumluluk düzeyleri üzerinde durulmuştur.

\section{I- ÖZEL SAĞLIK HIZMET SUNUCULARI}

5510 sayılı Kanun uygulamasında sağlık hizmet sunucusu, sağlık hizmetini sunan ve/veya üreten; gerçek kişiler ile kamu ve özel hukuk tüzel kişilerini ve bunların tüzel kişiliği olmayan şubelerini kapsamaktadır (5510/3.25 md). Özel sağlık hizmet sunucusu ifadesi sağlık hizmeti üretim ve sunumu yapılan gerçek ya da özel hukuk tüzel kişilerine ait sağlık kurum ve kuruluşlarını (Bilgili, 2009: 56-70) ihtiva etmektedir.

Sağlık hizmetleri koruyucu, tedavi edici ve rehabilite edici hizmetler olmak üzere üç ana grupta sınıflandırılmaktadır. Sağlık hizmet sunucularını basamaklandırma yetkisi ise Sağlık Bakanlığına aittir. Gerçekten de 5510 sayılı Kanun'un uygulanması bakımından sağlık hizmeti sunucuları birinci, ikinci ve üçüncü basamak olarak Sağlık Bakanlığı tarafından basamaklandırılır (5510/70.1 md). Sosyal Güvenlik Kurumu Sağlık Uygulama Tebliğinin ${ }^{5}$ (1.4) maddesinde, Sağlık hizmetlerinin sınıflandırılması da dikkate alınarak sağlık hizmeti sunucuları Sağlık Bakanlığınca aşağıdaki şekilde basamaklandırılmıştır (SB, 2019).

Birinci basamak sağlık kuruluşları, ilgili mevzuatında tanımlanan, hastaların ayaktan veya yataklı teşhis ve tedavilerinin yapıldığı sağlık kuruluşlarıdır. Buna göre birinci basamak özel sağlık kuruluşları şunlardır:

1- İşyeri hekimlikleri,

2- Evde Bakım Hizmetleri Sunumu Hakkında Yönetmelik kapsamında hizmet veren merkez veya birimler,

3- Ayakta Teşhis ve Tedavi Yapılan Özel Sağlık Kuruluşları Hakkında Yönetmelik kapsamında açılan özel poliklinikler,

4- Ağız ve Diş Sağlığı Hizmeti Sunulan Özel Sağlık Kuruluşları Hakkında Yönetmelik kapsamında açılan ağız ve diş sağlığı hizmeti veren özel sağlık kuruluşları,

5- Eczacilar ve Eczaneler Hakkında Kanun kapsamında serbest faaliyet gösteren ve birinci basamak sağlık kuruluşu olan eczaneler.

Öte yandan, Sağlık Bakanlığı tarafından basamaklandırılamayan ancak özel sağlık kuruluşları kapsamında değerlendirilen sağlık hizmet sunucuları da bulunmaktadır. Bunları da şu şekilde sıralayabiliriz:

1- Sağlık Bakanlığından ruhsatlı özel diyaliz merkezleri ile diğer özelleşmiş tedavi merkezleri (Üreyeme yardımcı tedavi merkezleri, hiperbarik oksijen tedavi merkezleri, vd.)

2- Özel tanı, tetkik ve görüntüleme merkezleri ile laboratuvarlar,

3- Özel optisyenlik müesseseleri,

4- Özel tıbbi cihaz ve malzeme tedarikçileri,

5- Özel kaplicalar,

6- Beşeri tıbbi ürün/ürün sunan ve/veya üreten özel hukuk tüzel kişileri ve bunların tüzel kişiliği olmayan şubeleri.

İkinci basamak sağlık kurumları, ilgili mevzuatında tanımlanan ayaktan veya yataklı teşhis, tedavi ve rehabilitasyon hizmeti verilen sağlık kurumlarıdır. İkinci basamak özel sağlık kurumları ise şunlardır:

\footnotetext{
${ }^{5}$ 24/03/2013-28597 RG.
} 
1-Özel Hastaneler Yönetmeliğine göre ruhsat almış hastaneler,

2-Ayakta Teşhis ve Tedavi Yapılan Özel Sağlık Kuruluşları Hakkında Yönetmelik kapsamında açılan tıp merkezleri,

3-Ayakta Teşhis ve Tedavi Yapılan Özel Sağlık Kuruluşları Hakkında Yönetmeliğin geçici ikinci maddesine göre faaliyetlerine devam eden tıp merkezleri ve dal merkezleri.

Üçüncü basamak sağlık kurumları, ilgili mevzuatında tanımlanan ileri tetkik ve özel tedavi gerektiren hastalıklar için yüksek teknoloji içeren ve/veya eğitim ve araştırma hizmetlerinin verilebileceği altyapıya sahip sağlık kurumlandır. Üçüncü basamak sağlık kurumları, kurum harici veya il dışından üçüncü basamak sağlık hizmeti ihtiyacı için sevkle gelen hastaların kabulünü yapabilmeli ve sağlık hizmeti ihtiyaçlarını karşılayabilmelidir. Sağlık Bakanlığı, vakıf üniversitelerine ait hastaneler ile bunlara bağlı sağlık uygulama ve araştırma merkezlerini "üçüncü basamak özel sağlık kurumu" olarak basamaklandırmamıştır (SB, 2019).

Sosyal Güvenlik Kurumu Sağlık Uygulama Tebliğinin (1.4.1) ve (1.4.2) maddelerinde ise üçüncü basamak özel sağlık hizmet sunucusu diye bir ayrıma gidilmemiştir. Devlet ve vakıf üniversiteleri ayrımı yapılmaksızın tüm üniversitelerin medikososyal birimleri "birinci basamak resmi sağlık kuruluşu" sayılırken, yine Devlet ve vakıf üniversiteleri ayrımı yapılmaksızın bütün üniversite hastaneleri ile bu hastanelere bağlı sağlık uygulama ve araştırma merkezleri, enstitüler ve semt poliklinikleri, üniversitelerin diş hekimliği fakülteleri "üçüncü basamak resmi sağlık kurumu” sayılmıştır. Anlaşılacağı üzere, 5510 sayılı Kanun'un ek 10.maddesi uygulamasında özel hukuk kişileri ile vakıf üniversitelerine ait sağlık kurum ve kuruluşları aynı statüde değerlendirilmiştir.

\section{II- ÖZEL SAĞLIK HIZZMET SUNUCULARINDA HEKIMM ISTIHDAMI}

\section{A- Genel Olarak}

Özel sağlık hizmet sunucularında şüphesiz hekimler dışında da sağlık personeli ve diğer yardımcı personel istihdam edilmektedir. Hekim dışı personelin istihdamında, özel sağlık hizmet sunucusu ile hekim dışı personel arasındaki iş ilişkisinin hizmet akdine dayalı olması ve 4/a statüsünde sigortalı sayılmaları konusunda herhangi bir tartışma bulunmamaktadır. Ancak, hekimlerin özel sağlık hizmet sunucularında istihdamı farklı şekillerde olabilmektedir.

Hekimlerin özel sağlık hizmet sunucularında çalıştırılmalarında 23/04/2015 tarihine kadar herhangi bir ayrım bulunmamakta, hizmet akdi ile çalışmaktaydılar. Bu şekildeki çalışma ilişskileri sonucunda 4/a statüsünde sigortalı sayılmaktaydılar. Ancak, 6645 sayılı Kanun ile 5510 sayılı Kanun'a ilave edilen ek 10. maddenin ikinci fikrasıyla 23/04/2015 tarihinden itibaren iki farklı şekilde hekim istihdamına imkan tanınmış oldu.

Özel sağlık hizmet sunucularında istihdam edilen hekimlerin sosyal sigortalılıkları 4/a statüsünde olabileceği gibi 4/b statüsünde de olabilir. Yani hekimler "işçiler" gibi sosyal sigortalı olabileceği gibi “bağımsız çalışanlar” gibi de sosyal sigortalı sayılabilir.

Buna göre, özel sağlık kurum ve kuruluşları ya da vakıf üniversitelerinin, mesleğini serbest olarak icra eden hekimlerden serbest meslek makbuzu veya şirket ortağı olan hekimlerden şirketleri vasıtası ile fatura mukabilinde "hekimlik hizmeti satın alma sözleşmesi” yaparak hekim çalıştırmaları mümkün hale getirilmiştir. Aynı şekilde "hizmet akdi" ile hekim çalıştırılması da mümkündür. Bu farklı sözleşmelere dayalı hekim istihdamının ise tabi olunan sosyal sigortalılık statülerini etkilediğini söyleyebiliriz. 
Özel Sağlık Hizmet Sunucularında Çalışan Hekimlerin Sigortalılı̆̆1

Mesleğini serbest olarak icra eden hekimlerin, hizmet bedeli hasta tarafından karşılanmak suretiyle Sosyal Güvenlik Kurumu ile sözleşmeli vakıf üniversiteleri dahil özel sağlık hizmet sunucularında, o sağlık kurum ve kuruluşlarının fiziki ve teknik kapasitesini kullanmak suretiyle kendi hastalarını teşhis ve tedavi etmeleri ise o özel sağlık hizmet sunucusunun hekim istihdamı olarak değerlendirilmemelidir. Konu aşağıda ayrıca açıklanmıştır.

\section{B- Hekim ile Özel Sağlık Hizmet Sunucusu Arasındaki İş İlişsisinin Sigortalılık Niteliğine Etkisi}

\section{i ) Hizmet Akdine Dayalı İş İlişkisi}

Hizmet akdi ile çalışan hekimin, çalışma ilişkisine girdiği sırada bir başka yerde hiç çalışmamasının ya da çalışmasının, şirket ortağı olmasının veya muayenehane sahibi olarak gelir vergisi mükellefi olmasının sonuca etkisi bulunmamaktadır. Hekim hizmet akdi ile çalışması halinde 4/a kapsamında sigortalı sayılacaktır. 5510 sayılı Kanunda ise ayrı bir hizmet akdi ya da iş sözleşmesi (hizmet sözleşmesi) tarifine yer verilmemiş, Türk Borçlar Kanunu'nda ${ }^{6}$ tanımlanan hizmet akdi ve iş mevzuatında tanımlanan iş sözleşmesi veya hizmet akdi esas alınmıştır (5510/3.11 md). Özel sağlık hizmet sunucularında hizmet akdi ile çalışan hekimler de 4/a statüsünde sigortalı sayılacaktır.

Buna göre, "İ̧s sözleşmesi, bir tarafin (işçi) bağımlı olarak iş görmeyi, diğer tarafin (işveren) da ücret ödemeyi üstlenmesinden oluşan sözleşmedir” (4857/8.1 md). "Hizmet sözleşmesi, işçinin işverene bağımlı olarak belirli veya belirli olmayan süreyle işgörmeyi ve işverenin de ona zamana veya yapılan işe göre ücret ödemeyi üstlendiği sözleşmedir"'(6098/393.1 md). $\mathrm{Bu}$ tanımlara göre hizmet akdinin unsurları bir işin görülmesi, işin bir ücret karşılığı görülmesi ve işin işverene bağımlı olarak görülmesidir (Ekmekçi ve Yiğit, 2020: 15-23; Eyrenci, Taşkent ve Ulucan, 2019: 61-63; Süzek, 2018: 223-231; Çelik, Canbolat ve Caniklioğlu, 2019: 168-177).

Hizmet akdi ile çalışan birisinin 4/a statüsünde sigortalı sayılabilmesi için ise iş ilişkisinin kural olarak hizmet akdine dayanması, işin işverene ait işyerinde veya işyerinden sayılan yerlerde yapılması ve çalışanların "sigortalı sayılmayanlar" arasında bulunmaması gerekmektedir. Bu koşullar aynı anda gerçekleşmelidir. İşverene ait işyerinde çalışma koşulunun ise yeni çalışma biçimleri karşısında işverene ait iş organizasyonu kapsamında yerine getirilmesi olarak anlaşılması gerekmektedir (Güzel, Okur ve Caniklioğlu, 2020: 8090; Tuncay ve Ekmekçi, 2019: 302-308; Sözer, 2019:69-75).

Sigortalılığın oluşumu yönünden çalışma olgusunun varlığı zorunludur. Eylemli veya gerçek biçimde çalışmanın varlığı saptanmadıkça, sigortalılıktan söz edilemez ${ }^{7}$. Eylemli veya gerçek biçimde çalışmanın varlığı saptanmadıkça, hizmet akdine dayanılarak dahi sigortalılıktan söz edilemez ${ }^{8}$. Fiili çalışma saptanmadıkça, sadece hizmet akdine dayanılması halinde sigortalılık söz konusu olamaz ${ }^{9}$. Öyle ki; yöntemince düzenlenip süresinde Kuruma verilen işe giriş bildirgesi, kişinin işe alındığını gösterir ise de fiili çalışmanın varlığının ortaya konulması açısından tek başına yeterli kabul edilemez ${ }^{10}$. Geçerli olmayan bir hizmet

${ }^{6}$ 04/02/2011-27836 RG.

7 Y.10.HD., 03/05/2005, E: 2005/2383, K:2005/489; Çalışma ve Toplum. 2005/4-7. 275-276.

8 YHGK., 06/07/2005, E:2005/21-437, K:2005/448; Çalıșma ve Toplum. 2005/4-7.109-112.

9 Y.10.HD., 10/03/2014, E:2013/22210, K:2014/5171; Çalışma ve Toplum. [45; file:///C:/Users/Akademik /Downloads/yargitay-kararlari-4007-50c955c5.pdf] (Erişim : 03 Aralık 2020)

${ }^{10}$ Y.10.HD., 27/09/2010, E:2010/6174, K:2010/12163; Çalışma ve Toplum. 2011/2-29. 566-570; Y.10.HD., 01/10/2018, E:2018/3494, K:2018/7254; Çalışma ve Toplum. 60 file://C:/Users/Akademik/Downloads/yargitay-kararlari-2804-154ce796.pdf] (Erişim: 03 Aralık /2020) 
akdine dayanarak olsa bile fiilen çalışanlar geçersizliğin saptandığı tarihe kadar sigortalı sayılacaklardır ${ }^{11}$.

\section{ii ) Hizmet Alım Sözleşmesine Dayalı İş İlişkisi}

Şirket ortağı olan veya mesleğini serbest olarak icra eden hekimler ile tıpta uzmanlık mevzuatına göre uzman olan kişilerin, hizmet alım sözleşmesi ile özel hukuk kişileri ve/veya vakıf üniversitelerine ait sağlık kurum ve kuruluşları bünyesinde hizmet vermeleri halinde, hizmet alım sözleşmelerinde aksine bir hüküm bulunmadığı sürece 23/04/2015 tarihinden geçerli olmak üzere 4/b kapsamında sigortalı sayılacaklardır. Öte yandan, 23/04/2015 tarihinden önce 4/a kapsamında sigortalı olarak çalışılan sürelere ilişkin haklar saklıdır (5510/ek $10.2 \mathrm{md})$. Anlaşılacağ1 üzere, hizmet alım sözleşmesi metni içerisinde hekim çalışmasının 4/a kapsamında sigortalı olarak bildirilmesine ilişkin özel bir hüküm var ise hekimler 4/a statüsünde sigortalı sayılacak, aksi halde 4/b kapsamında sigortalı oldukları kabul edilecektir.

5510 sayılı Kanun'un ek 10. maddesi kapsamında, hizmet alım sözleşmesi ile özel hukuk kişileri ve/veya vakıf üniversitelerine ait sağlık kurum ve kuruluşları bünyesinde hizmet verecek olan, şirket ortağ 1 olan veya mesleğini serbest olarak icra eden hekimler ile tıpta uzmanlık mevzuatına göre uzman olan kişilerin, çalıştığında aylığı kesilmeyenlerden olup Sosyal Güvenlik Kurumundan yaşlılık/emekli aylığı almaları durumunda ise 4/b statüsünde sigortalı olmaları dahi sözkonusu olmayacaktır. 29/01/2016 tarih ve 6663 sayılı Kanun ile 5510 sayılı Kanun'un 30 ve geçici 14.maddelerinde yapılan değişiklikler uyarınca, 01/03/2016 tarihinden geçerli olmak üzere; ilk defa 2008 yılı Ekim ayı başından sonra sigortalı olup yaşlılık aylığı bağlananların $4 / \mathrm{b}$ statüsünde sigortalı sayılmayı gerektirecek şekilde çalışmaları halinde aylıklarının kesilmeyeceği, ilk defa 2008 yılı Ekim ayı başından önce sigortalı olan veya aylık alanların 4/b statüsünde sigortalı sayılmayı gerektirecek şekilde çalışmaları halinde ise sosyal güvenlik destek primine tabi olmayacakları hüküm altına alınmıştır. Bu çalışma artık sigorta ilişkisi yaratmamaktadır (Güzel, Okur ve Caniklioğlu, 2020: 603-604; Tuncay ve Ekmekçi, 2019: 200).

Görüldügü üzere emekli hekimlerden hizmet alınması halinde 4/b statüsünde sigortalılık hali dahi sözkonusu olmamaktadır. Hizmet alım sözleşmesinde emekli hekimin 4/a statüsünde sigortalı sayılmasına dönük özel bir hüküm olması halinde ise sosyal güvenlik destek primine tabi olacağı muhakkaktır. Ancak emekli hekim dilerse aylığının kesilmesine yönelik tercih bildiriminde bulunup tüm sigorta kollarına tabi olmak isteyebilir. Bu tercih işe giriş bildirgesinde yapılabilecektir. Kaldı ki, 4/a kapsamındaki hizmetleri ile yaşlılık aylığı bağlanan sigortalılar aylık bağlandıktan sonra çalışmaya başladıkları işyerlerinde işe giriş bildirgesinde tüm sigorta kollarına tabi çalışmayı tercih edebilecekleri gibi, aynı işveren yanında çalışmalarının devam etmesi halinde "Sigortalı Tercih Bildirim Formu" ile sosyal güvenlik destek primine tabi çalışarak aylıklarının yeniden bağlanmasını talep edebilmekte ya da aylıklarını kestirmeyip düzenlenecek işe giriş bildirgesinde sosyal güvenlik destek primini seçebilecekleri gibi aynı işveren yanında çalışmalarının devam etmesi halinde "Sigortalı Tercih Bildirim Formu" ile aylıklarını kestirip tüm sigorta kollarına tabi olmayı tercih edebilmektedir (SGK, 2013).

Sözkonusu düzenleme ile sadece Sosyal Güvenlik Kurumu ile sözleşmeli özel sağlık hizmet sunucuları değil özel hukuk kişileri ve/veya vakıf üniversitelerine ait tüm sağlık kurum ve kuruluşları kapsama alınmıştır. Bu kapsamdaki sağlık hizmet sunucuları yine fiilen sağlık

\footnotetext{
${ }^{11}$ Y.10.HD., 20/05/1997, E:1997/3791, K:1997/3965; Aydınlı, İ.(1998). İş Hukukunda Butlan (Geçersizlik)'ın Uygulanmasına İlişkin Yargıtay Kararı İncelemesi. Çimento İşveren. 12(2). (Erişim: 01 Aralık 2020)
} 
kuruluşu işleten şirketlerin ortağı hekimler ile veya fiilen muayenehane işleterek mesleğini serbest olarak icra eden hekimler ile hekimlik hizmeti satın alma sözleşmeleri yapabilecektir.

Yapılan bu düzenlemenin sosyal güvenliğin temel ilkeleri dikkate alındığında, çalışma hayatının esnekleşmesine, giderek esnek sosyal güvenlik uygulamalarına bir örnek teşkil ettiği söylenebilir. Özel sağlık hizmet sunucularında çalışan hekimlerin kural olarak 4/b kapsamında sayılmasından dolayı sigorta primlerini kendilerinin ödemesinin, özel sağlık hizmet sunucularının sigorta prim yüklerini azaltacağı beklenebilir.

Öte yandan, özel sağlık hizmet sunucularındaki hekim çalışmasının 4/b kapsamına alınmasına ilişkin bürokratik işlemlerin azaltılmaya çalışıldığı anlaşılmaktadır. Örneğin Sağlık Bakanlığı, özel sağlık hizmet sunucularında çalışacak hekimler için il sağlık müdürlüklerince çalışma belgesi düzenlenirken ya da çalışma belgeleri onaylanırken istenen belgeler arasında daha önce yer alan "sigortalı işe giriş bildirgesi", "sağlık hizmet sunucusu ile hekim arasında düzenlenen hizmet akdi", "mesul müdür ve yardımcıları ile bazı özel sağlı hizmet sunucuları için tabip odası kaydı", "vergi levhası", vb. belgelerin artık istenilmemesini talimatlandırmıştır (SB., 2020).

5510 sayılı Kanun'un ek 10.maddesi ile, fiilen herhangi bir muayenehanesi olmadan, il sağlık müdürlüklerince muayenehane ruhsatı dahi verilmeksizin, ikamet adresleri işyeri adresi gösterilerek "ev ofis" tarzında çalışacakları beyanıyla hekimlere vergi dairelerinden mükellef kaydı oluşturulabilmektedir. Vergi dairelerinden düzenlenen vergi levhalarında, "862202Özel muayenehanelerde sağlanan uzman hekimlik ile ilgili yatıl olmayan uygulama faaliyetleri” veya “ 862104- Özel muayenehanelerde sağlanan yatılı olmayan genel hekimlik uygulama” kodları ile hekimler için vergi mükellefiyetleri tesis edilebilmektedir.

Özel sağlı hizmet sunucuları da bu şekilde vergi kaydı oluşturan hekimler ile hizmet satın alma sözleşmesi yaparak il sağlık müdürlüklerine başvurup ya çalışma belgesi düzenlenmesini ya da düzenledikleri çalışma belgelerinin onaylanmasını istemektedir. Belirtilen durumlarda il sağlık müdürlüklerince Sağlık Bakanlığı çekirdek kaynak yönetim siteminden (ÇKYS) yapılan sorgulamada başvurusu yapılan hekim adına ve belirtilen adresinde ruhsatlı muayenehaneye rastlanmamaktadır ${ }^{12}$. Esasen yaygın biçimde işlemlerin kağıt üzerinde yapılması gibi bir uygulamaya meydan verildiği görülmektedir.

Denilebilir ki, 5510 sayılı Kanunda sadece "mesleğini serbest olarak icra eden hekim" (muayenehanesi olan hekim) ile "şirket ortağı olan hekimden" söz edilmiş, fiilen sağlık kuruluşu işletmeleri üzerinde durulmamıştır. Bu sebeple de kağıt üzerinde şirket ortağı olunması ya da muayenehane için vergi mükellefiyeti tesis ettirilmesi yeterlidir!. Ancak Kanunun lafzından bu sonuca ulaşmak en başta 4721 sayılı Türk Medeni Kanunu'nun ${ }^{13}$ 2.maddesindeki, "Herkes, haklarını kullanırken ve borçlarını yerine getirirken dürüstlük kurallarına uymak zorundadır. Bir hakkın açıkça kötüye kullanılmasını hukuk düzeni korumaz.” ilkesine aykırılık teşkil eder. Ayrıca sağlık mevzuatına da açıkça aykırılık sözkonusudur. Hekim sadece herhangi bir şirketin ortağı değil de fiilen sağlık kuruluşu işleten bir şirkete ortak olmalıdır. Keza, hekimin kağı üzerinde muayenehane açması değil

\footnotetext{
${ }^{12}$ ÇKYS (Çekirdek Kaynak Yönetim Sistemi): Sağlık Bakanlığının, bakanlığın tüm personelinin, kurum ve bina bilgileri, malzeme bilgisi ve özel sağlık kuruluşlarının izlendiği sistemdir. Personel hareketlerinin takip edildiği İnsan Kaynakları Yönetim Sistemi (İKYS), Sağlık Bakanlığı bünyesindeki tüm malzeme depolarındaki taşınırların aktif olarak takip edildiği Malzeme Kaynakları Yönetim Sistemi (MKYS), taşınmaz takibinin yapıldığı Yatırım Takip Sistemi (YTS), Türkiye de faaliyet gösteren tüm özel sağllk kuruluşlarına ait bütün işlem adımlarının takip edildiği Özel Sağlık Kuruluşları Yönetim Sistemi (SKYS) ve ülke genelinde sağlık istatistikleri toplamak için kullanılan Temel Sağlık İstatistikleri Modülü (TSIM) gibi alt modüllere sahiptir.

${ }^{13} 08 / 12 / 2001-24607$ RG.
} 
kanunun ruhuna uygun olarak ruhsatlı muayenehanesinde fiilen mesleğini serbestçe icra etmelidir.

Öte yandan, Bankalar ve Kamu İdareleri Tarafından Yapılacak Olan Sigortalılık Kontrolü ile Kurum ve Kuruluşlardan Alınacak Bilgi ve Belgelere Dair Tebliğin ${ }^{14}$ 20.maddesi uyarınca, Sağlık Bakanlığı (il sağlık müdürlükleri) sağlık mevzuatı kapsamında, verilen yetki belgesi, denetim sırasında çalışanlara ait bilgiler, mesul müdürlük ve personel çalışma izin belgesi örnekleri, ayrıca çalışan kişilerin T.C. Kimlik Numaralı işyeri sahibi/işyeri çalışanı ayrımlı kimlik bilgileri ve çalışılan yerin unvanı ve açık adresi bilgileri ile varsa ücreti ve işe başlama tarihi bilgilerini Sosyal Güvenlik Kurumuna göndermektedir. Sosyal Güvenlik Kurumu da bildirimi yapılan kişilerin kayıt dışı istihdam ile mücadele bağlamında sigortalılık kontrollerini yapmaktadır (SGK, 2015a).

Sosyal Güvenlik Kurumu özel sağlık hizmet sunucularından hekimlerin 4/a statüsünde sigortalı bildirimi yapılmasını ise şüpheli bir işlem sayacak ve hekim sigortalılara ilişkin kontrol yapacaktır. Bu defa yapılacak kontrol kayıt dışı istihdama ilişkin değil de "hekim 4/b kapsamında sigortalı olması gerektiği halde acaba neden 4/a kapsamında sigortalı bildirimi yapılmış?" şüphesi üzerine olacaktır. Şirket ortağı olan veya mesleğini serbest olarak icra eden hekimler ile tıpta uzmanlık mevzuatına göre uzman olan kişilerin, özel sağlık hizmeti sunucuları tarafından 4/a kapsamında bildirimlerinin yapılması halinde, özel sağlık hizmet sunucuları ile yaptıkları hizmet alım sözleşmesinin onaylı bir örneği sağlık hizmet sunucusundan istenilecek ve sözleşme metninde çalışmanın 4/a kapsamında bildirilip bildirilmeyeceğine ilişkin bir hükmün olup olmadığı kontrol edilecektir. Hizmet alım sözleşmesi metni içerisinde çalışmanın 4/a kapsamında bildirilmesine ilişsin özel bir hükmün bulunması halinde yapılan bildirimler geçerli kabul edilecek, aksi halde yapılan bildirimler iptal edilerek 4/b kapsamında sigortalı sayılacaklardır (SGK, 2015b).

Öyle ki, şirket ortağı olan veya mesleğini serbest olarak icra eden hekimler ile tıpta uzmanlık mevzuatına göre uzman olan kişilerin 4/a kapsamında çalışmaları devam ederken, özel hukuk kişileri ve/veya vakıf üniversitelerine ait sağlık kurum ve kuruluşları bünyesinde 6645 sayılı Kanun'un yayımlandığı 23/04/2015 tarihinden sonra hizmet alım sözleşmesi imzalamak suretiyle hizmet vermeye başlamaları ve sözleşmelerinde aksine bir hüküm bulunmaması halinde, hizmet alım sözleşmesinin imzalandığ tarih itibariyle 4/b kapsamında sigortalılıkları başlatılacaktır (SGK, 2015b).

Görüldügü üzere vakıf üniversitelerine ait olanlar dahil özel sağlık hizmet sunucularının hizmet alım sözleşmesi ile hekim çalıştırmaları halinde hekimler kural olarak 4/b statüsünde sigortalı sayılmakta, hizmet alım sözleşmesinde özel bir hüküm ile hekimlerin 4/a kapsamında sigortalı bildirimleri kabul edilmiş ise ancak bu durumda 4/a kapsamında sigortalılığa geçerlik tanınmaktadır. Belirtilim ki, hekimler hizmet satın alım sözleşmesi olmaksızın, öteden beri olduğu üzere hizmet akdi ile çalıştırıldıklarında 4/a statüsünde sigortalı sayılacaklardır.

\section{iii) Özel Sağlık Hizmet Sunucusu İşyerinin Kullanımına Dayalı İş İlişkisisi}

Sosyal Güvenlik Kurumu ile sözleşmeli özel sağlı hizmet sunucuları ve/veya vakıf üniversitelerine ait sağlık hizmet sunucularında, kendi hastalarını teşhis ve tedavi eden mesleğini serbest icra eden hekimler ise 4/b kapsamında sigortalı sayılmaya devam edeceklerdir. $\mathrm{Bu}$ kapsamdaki hekimler serbest meslek kazancı sebebiyle gelir vergisi mükellefi oldukları için 5510 sayılı Kanun'un 4.maddesi birinci fikrasının (b) bedinin (1) numaralı alt bendi uyarınca sigortalı sayılacaklardır. Hekimin bu şekildeki çalışması "hizmet

${ }^{14} 10 / 06 / 2014-29026$ RG. 
Özel Sağlık Hizmet Sunucularında Çalışan Hekimlerin Sigortalılığ1

akdine dayalı bir iş ilişkisi” olmadığı gibi 5510 sayılı Kanun'un ek 10.maddesinde sözü edilen "hizmet satın alma sözleşmesine dayalı bir iş ilişkisi" de değildir. Bu çalışma ilişkisinde muayenehanesi olup mesleğini serbestçe icra eden hekim, sağlık hizmet sunucusu ile yaptığı anlaşmaya uygun olarak ve o özel sağlık hizmet sunucusunun fiziki mekan, teknik ve personel imkanlarını kullanarak kendi hastalarını o özel sağlık hizmet sunucusunda teșhis ve tedavi etmektedir.

Sağlık hizmet sunucusu işyerinin kullanımına dayalı bu iş ilişkisinde hekim sağlık hizmet sunucu tarafından çalıştırılmamaktadır. Dahası mesleğini serbestçe icra eden hekim anlaştığı özel sağlık hizmet sunucusuna bir ödeme yapmamaktadır. Hizmetin bedeli tedavi ettiği hasta tarafından o özel sağlık hizmet sunucusuna ödenmektedir. Bu sebeple de belirtilen kapsamda hasta tedavi eden hekimlerin sigortalılık niteliklerinin belirtilmesi ile yetinilmiş, aşağıdaki diğer bölümlerde bunlar için ayrı bir başlık açılmamıştır.

Mesleğini serbestçe icra eden hekimin sağlık hizmet sunucusu ile bu şekilde yaptığ 1 anlaşmanın dayanağını ise 1219 sayılı Tababet ve Şuabatı San'atlarının Tarzı İcrasına Dair Kanun ${ }^{15}$ oluşturmaktadır. 1219 sayılı Kanun'un 21/01/2010 tarihli ve 5947 sayılı Kanun ile değişik 12.maddesi üçüncü fikrasında “...Mesleğini serbest olarak icra edenler, hizmet bedeli hasta tarafindan karşılanmak ve Sosyal Güvenlik Kurumundan talep edilmemek kaydıyla, (b) bendi kapsamında sayılan sağlık kuruluşlarında (Sosyal Güvenlik Kurumu ve kamu kurumları ile sözleşmeli çalışan özel sağlık kurum ve kuruluşları, Sosyal Güvenlik Kurumu ve kamu kurumları ile sözleşmeli çalıșan vakıf üniversiteleri) da hastalarının teşhis ve tedavisini yapabilir...” hükmüne yer verilmiştir.

Belirtelim ki bu iş ilişsisinde sadece hekim ya da uzman hekimler değil mesleğini serbestçe icra eden diş hekimleri de taraf olabilmektedir. Sağlık kurum ve kuruluşu işleten şirketlerin ortağ 1 hekim ya da diş hekimleri ise bir başka sağlık hizmet sunucusu ile bu türlü bir iş ilişkisine girememektedir.

Öte yandan, mesleğini serbest olarak icra eden hekim ya da diş hekimlerinin fiziki mekan, teknik ve personel imkanlarını kullanmak üzere anlaşma yapacağı özel sağlık hizmet sunucuları ise sadece Sosyal Güvenlik Kurumu ve diğer kamu kurumları ile sözleşmeli çalışan özel sağlık kurum ve kuruluşları ile vakıf üniversiteleridir. 2018 tarihli Sosyal Güvenlik Kurumu Özel Sağlık Hizmeti Sunucularından Sağlık Hizmeti Satın Alım Sözleşmesinin ${ }^{16}$ 5.maddesi uyarınca sağlık hizmet sunucusu, Sosyal Güvenlik Kurumu ile sözleşmeli özel sağlık hizmet sunucuları ise Sağlık Uygulama Tebliğinde (SUT) belirtilen ikinci basamak özel sağlık kurumları ile diyaliz merkezleri ve Sağlık Bakanlığından ruhsatlı diğer özelleşmiş tedavi merkezleridir. Dolayısıyla sadece özel hastaneler, özel tıp merkezleri özel dal merkezleri ile özel diyaliz merkezleri, üremeye yardımcı tedavi merkezleri, hiperbarik oksijen tedavi merkezleri ve Sağlık Bakanlığından ruhsatlı diğer özelleşmiş tedavi merkezleriyle belirtilen anlaşmalar yapılabilecektir.

\section{iv ) Sigortalılık Hallerinin Çakışmasının Hekimin Sigortalılığına Etkisi}

5510 sayılı Kanun'un ek 10.maddesi ile hekim sigortalılığında 4/b statüsüne öncelik tanındığ görülmektedir. Düzenlemenin bu haliyle sigortalılık hallerinin çakışması durumunda evvela 4/c, ardından da 4/a statüsüne öncelik tanınmasına ilişkin temel ilkeden ayrıldığı söylenebilir (Ermumcu, 2009; Ekin, 2016; Karaman, 2014; Kayık, 2015). 5510 say1lı Kanun uygulamasında 01/10/2008-28/02/2011 tarihleri arasındaki dönemde sigortalının 4/a ve 4/b sigortalılık hallerine aynı anda tabi olmasını gerektirecek şekilde çalışması halinde ilk önce

\footnotetext{
${ }^{15}$ 14/04/1928- 863 RG.

${ }^{16}$ https://kms.kaysis.gov.tr/Home/Kurum/22620739, Erişim.15/11/2020.
} 
başlayan sigortalılık ilişkisi esas alınarak sigortalı sayılmaktaydı. 01/03/2011 ve sonrası dönemde ise sigortalının 4/a ve 4/b sigortalılık hallerine aynı anda tabi olmasını gerektirecek şekilde çalışması halinde 4/a kapsamında sigortalı sayılmaya başlanmıştır ${ }^{17}$.

Sigortalılık hallerinin çakışması durumunda çözüme ilişkin kanuni düzenlemenin son haline göre ise, "Sigortalının 4.maddenin birinci fikrasinın (a) ve (b) bentlerinde yer alan sigortalılık statüleri ile (c) bendinde yer alan sigortalılık statüsüne aynı anda tabi olacak şekilde Kanun kapsamına girmesi halinde öncelikle aynı maddenin birinci fikrasının (c) bendi kapsamında, (a) ve (b) bentlerinde yer alan sigortalllık statülerine tabi olacak şekilde Kanun kapsamına girmesi halinde ise aynı maddenin birinci fikrasının (a) bendi kapsamında sigortalı sayllır...” (5510/53.1 md). Bu düzenleme ile sigortalılık hallerinin üstünlük (öncelik) sıralaması sırasıyla 4/c, 4/a ve 4/b şeklinde değiştirilmiştir. Böylece, 4/a ve 4/b sigortalılık hallerinin çakışması halinde 4/a sigortalılık ilişkisine öncelik verilmiştir (Uşan, 2016). Sosyal sigorta yardımları ile genel sağlı sigortası açısından 4/a statüsündeki sigortalılar lehine olan örnek durumlara aşağıda yer verilmiştir.

Şirket ortağı olan veya mesleğini serbest olarak icra eden hekimler ile tıpta uzmanlık mevzuatına göre uzman olan kişiler bu halleriyle 4/b statüsünde sigortalı sayılırlar. Ancak, özel hukuk kişileri ve/veya vakıf üniversitelerine ait sağlık kurum ve kuruluşları bünyesinde hizmet alım sözleşmesi ile çalıştırılsalar bile 4/a kapsamında sigortalı sayılmaları beklenirken, hizmet alım sözleşmelerinde 4/a kapsamında bildirimleri yapılacağına dair özel bir hükme yer verilmediği sürece 4/b kapsamında sigortalı sayılmaktadırlar.

\section{C- Özel Sağlık Hizmet Sunucusunda Çalışan Hekimler İşsizlik Sigortasına Tabi Midir?}

Kimlerin işsizlik sigortasına tabi oldukları 4447 sayılı İşsizlik Sigortası Kanunu'nun ${ }^{18}$ 46.maddesi ikinci fikrasında düzenlenmiş, "5510 sayll Sosyal Sigortalar ve Genel Să̆llk Sigortası Kanunu'nun 4'üncü maddesinin birinci fikrasının (a) bendi ile ikinci fikrası kapsamında olanlardan bir hizmet akdine dayalı olarak çalışan sigortalıların” kapsamda oldukları ifade edilmiştir (4447/46.2 md). Anlaşılacağ üzere, çalışanların işsizlik sigortasına tabi olabilmeleri için, tek başına 4/a kapsamında sigortalı olmaları yetmemekte, hizmet akdine dayalı olarak çalışmaları şartı da aranmaktadır. Dolayısıyla, işsizlik sigortasının kapsamı belirlenirken 5510 sayılı Kanuna göre 4/a statüsündeki sigortalılar esas alınacaktır. Bu hükme göre de hizmet akdi ile bir veya birden fazla işveren tarafından çalıştırılanlar 4447 sayılı Kanun uyarınca sigortalı sayılacaklardır (Bal Bektaş, 2014: 179).

4447 sayılı Kanun hükmü dikkate alındığında, 23/04/2015 tarihinden itibaren özel sağlık hizmet sunucuları ya da vakıf üniversiteleri ile hekimin ortak olduğu şirket arasında sağlık hizmeti verilmesi ve hekim tarafından verilen sağlık hizmeti bedellerinin de şirket tarafından düzenlenen fatura karşılığında sağlık hizmet sunucusu tarafından hekime değil hekimin ortağı olduğu şirkete ödenmesi amacıyla yapılan hizmet alım sözleşmeleri ile mesleğini serbest olarak icra eden hekimlerle özel sağlık hizmet sunucuları ya da vakıf üniversiteleri arasında serbest meslek makbuzu karşılığı hizmet alınmasına yönelik sözleşmelerin, Türk Borçlar Kanunu ve İş Kanunu'nda düzenlenmiş olan hizmet akdi unsurlarını taşımaması, bu sözleşmelere dayalı olarak hizmet alınan hekim ile sağlık hizmet sunucusu arasında isçi işveren ilişkisinin bulunmaması nedeniyle bu kapsamdaki hekimlerin söz konusu sağlık hizmet sunucularındaki çalışmalarının hizmet akdine dayalı olmadı̆̆ değerlendirilmektedir (SGK, 2020a).

\footnotetext{
${ }^{17}$ Y.21.HD., 08/02/2016 tarihli, E:2015/21899, K:2016/1357; Çalışma ve Toplum. file:///C:/Users/Akademik/Downloads/yargitay-kararlari-3442-481a203a.pdf. Erişim.07/12/2020

${ }^{18}$ 08/09/1999-23810 RG.
} 
Özel Sağlık Hizmet Sunucularında Çalışan Hekimlerin Sigortalılı̆̆1

Şu halde, 5510 sayılı Kanun'un ek 10.maddesi uyarınca sağlık hizmet sunucularında hizmet alım sözleşmeleri kapsamında çalıştırılan hekimlerin, 4/b kapsamında sigortalı sayıldıklarından işsizlik sigortasına tabi olmayacakları tartışmasızdır. Hizmet alım sözleşmelerinde var olan aksine bir hüküm ile 4/a statüsünde sigortalı bildirimi yapılması kararlaştırılan hekimler de işsizlik sigortasına tabi olmayacaklardır. Zira bunların çalışması hizmet akdine dayalı değildir. Belirtelim ki, 5510 sayılı Kanun'un ek 10.maddesi kapsamında olmayıp, sağlık hizmet sunucularında hizmet akdi ile çalıştırılan hekimler ise 4/a kapsamında sigortalı olarak aynı zamanda işsizlik sigortası hükümlerine tabi olacaktır.

Dolayısıyla, şirket ortağı olan veya mesleğini serbest olarak icra eden hekimler ile tıpta uzmanlık mevzuatına göre uzman olan kişilerin, sağlık hizmet sunucularında hizmet alım sözleşmesine dayalı olarak 4/a statüsündeki sigortalılık bildirimlerinde aktif sigortalı olmaları durumunda " 01 " belge türü değil de "13" belge türünün kullanılması gerekmektedir (SGK, 2016b). Yanlış ve yersiz olarak "01" belge türü kullanılmak suretiyle Sosyal Güvenlik Kurumuna ödenen işsizlik sigortası primleri, 5510 sayılı Kanun’un 89.maddesinin ikinci fikrası hükmü uyarınca, başvurulup talep edilmesi halinde sigortalı hissesi sigortalıya, işveren hissesi ise varsa borçlarına yoksa işverene iade edilebilecektir. 5510 sayılı Kanun'un ek 10.maddesi kapsamında olmayıp, sağlık hizmet sunucularında hizmet akdi ile 4/a kapsamında çalıştırılan hekimlerin ise " 01 " belge türünde bildirimleri yapılmalıdır (SGK, 2020b). Sosyal güvenlik destek primine tabi hekimler için ise "02" belge türü kullanılacaktır.

\section{III- HEKIMLERIN SIGGRTALILIK NITELIKLERININ SOSYAL GÜVENLIKK YARDIMLARINA ETKISI}

\section{A- Genel Olarak}

Özel sağlık hizmet sunucularında hizmet akdine tabi olarak çalıştırılan hekimler 4/a kapsamında sigortalıdırlar. 5510 sayılı Kanun'un ek 10.maddesi uyarınca da şirket ortağı olan veya mesleğini serbest olarak icra eden hekimler ile tıpta uzmanlık mevzuatına göre uzman olan kişilerin, hizmet alım sözleşmesi ile özel sağlık hizmet sunucularında hizmet vermeleri halinde, hizmet alım sözleşmelerinde aksine bir hüküm bulunması halinde yani sözleşme metni içerisinde hekimlerin 4/a kapsamında sigortalı olarak bildirilmesine ilişkin özel bir hüküm var ise hekimler 4/a statüsünde sigortalı kabul edilmektedir.

5510 sayılı Kanun'un ek 10.maddesi uyarınca, şirket ortağı olan veya mesleğini serbest olarak icra eden hekimler ile tıpta uzmanlık mevzuatına göre uzman olan kişiler, hizmet alım sözleşmesi ile özel hukuk kişileri ve/veya vakıf üniversitelerine ait sağlık kurum ve kuruluşları bünyesinde fatura ya da serbest meslek makbuzu mukabili hizmet vermeleri halinde, hizmet alım sözleşmelerinde aksine bir hüküm bulunmadığı sürece 23/04/2015 tarihinden geçerli olmak üzere 4/b kapsamında sigortalı sayılmaktadır.

Özel sağlık hizmet sunucularında hizmet alım sözleşmesi kapsamında 4/b statüsünde sigortalı olarak çalışan hekimler, "işçi” sayılmadıklarından 4857 sayılı İş Kanunu ${ }^{19}$ kapsamında da değildirler. Aşağıda, özel sağlık hizmet sunucularında çalışan hekimlerin sigortalılık niteliklerinin sosyal sigorta yardımları ve genel sağlık sigortası kapsamındaki haklarına etkisine yer verilmiştir

\section{B- Kısa Vadeli Sigorta Kolları Yönünden}

Hizmet alım sözleşmesi ya da hizmet akdi kapsamında özel sağlık hizmet sunucularında 4/a kapsamında sigortalı olarak çalışan hekimler, ayrımsız tüm kısa vadeli sigorta kolları hükümlerinden yararlanabilir. 4/a kapsamındaki hekimlerin, iş kazası ve meslek hastalığı

${ }^{19}$ 10/06/2003-25134 RG. 
sigortası, hastalık sigortası ve analık sigortası kollarından sağlanan geçici iş göremezlik ödeneği ve emzirme ödeneği verilmesi, sürekli iş göremezlik geliri bağlanması gibi sosyal sigorta yardımlarından yararlandırılmasında herhangi bir sınırlandırma ya da yasaklamaya gidilmemiştir. 4/a kapsamındaki hekimlerin sözkonusu sosyal sigorta yardımlarından yararlanmalarında kanunda aranan prim gün sayıları dışında örneğin "prim borcunun bulunmaması" gibi bir şart da bulunmamaktadır.

Hekimlerin 4/b kapsamında sigortalı sayılmalarının ise kısa vadeli sigorta kollarından sağlanan sosyal sigorta yardımları açısından önemli sonuçları bulunmaktadır. En başta 4/b statüsündeki hekimler hakkında hastalık sigortası hükümleri uygulanmayacaktır. Dolayısıyla hastalanıp istirahat raporu aldıklarında geçici iş göremezlik ödeneği alamayacaklardır (Güzel, Okur ve Caniklioğlu, 2020: 441; Şakar, 2017: 226; Sözer, 2019: 241-242; SGK, 2016a). Analık sigortası hükümleri şirket ortakları hariç tüm 4/b statüsündeki sigortalılar hakkında uygulanmaktadır (Sözer, 2019, s.255). Dolayısıyla, analık sigortası şirket ortağ $4 / \mathrm{b}$ kapsamındaki hekimler hariç, örneğin mesleğini serbestçe icra eden 4/b kapsamındaki kadın hekimler hakkında uygulanacaktır. Bu durumda da, şirket ortaklığı sebebiyle 4/b statüsünde sigortalı sayılan ve hizmet alım sözleşmesi ile özel sağlık hizmet sunucusunda çalışan bir kadın hekim doğum yaptığında, Sosyal Güvenlik Kurumundan analık sigortası kapsamında geçici iş göremezlik ödeneği alamayacaktır.

İş kazası ve meslek hastalığı sigortası kapsamında olmakla birlikte 4/b kapsamında sigortalı olarak özel sağlık hizmet sunucusu çalışanı hekimler için iş kazası sayılan hallerde bir sınırlama olacak ve uğranılan kazanın 5510 sayılı Kanun uyarınca 3 iş günü içerisinde Sosyal Güvenlik Kurumuna bildirim yükümlülüğü kendilerinde olacaktır. Ancak, 6331 sayılı İş Sağlığı ve Güvenliği Kanunu ${ }^{20}$ uyarınca “4/b statüsünde sigortalı olarak" kendi uğradıkları iş kazası ya da tutuldukları meslek hastalığını bildirme zorunlulukları bulunmamaktadır.

4/b kapsamında olanlar için örneğin iş kazası, 5510 sayılı Kanun'un 13 maddesi birinci fikrasının "(a)işyerinde bulunduğu sırada" ve "(b)yürütmekte olduğu işi dolayısılal" halleriyle sınırlı olmak üzere kabul edilecektir (Sözer, 2019: 364) Diyelim, özel sağlık hizmet sunucusu tarafından sağlanan bir taşıt ile işin yapıldığı yere gidip gelmesi sırasında uğradığı kaza iş kazası sayılmayacaktır. Uğradığı kazayı, bir ayı geçmemek şartıyla rahatsızlığının bildirim yapmaya engel olmadığı günden sonra üç işgünü içinde (5510/13.2-b md) bildirmeyen 4/b kapsamındaki hekim ise iş göremezlik ödeneğini ancak bildirim tarihinden itibaren alabilecektir (5510/22.2 md). Meslek hastalığı halinden de benzer durumların geçerli olduğunu söyleyebiliriz.

Belirtelim ki, sağlık hizmet sunucusunda 4/b kapsamında çalışan hekimlerin, analık sigortası ile iş kazası ve meslek hastalığı sigortası kapsamında sağlanan sosyal sigorta yardımlarından, örneğin geçici iş göremezlik ödeneği veya sürekli iş göremezlik gelirinden yararlanabilmesi için kendi sigortalılığından dolayı, genel sağlık sigortası dahil prim ve prime ilişkin her türlü borçlarının ödenmiş olması zorunludur (5510/18.d md; 5510/19.4 md). Anlaşılacağ üzere borcu olan hekimler sözü edilen sosyal sigorta yardımlarından yararlanamamaktadır (Alper, 2019, s.240).

Dikkat çeken bir hususa daha işaret etmeliyiz: Emekli/yaşlılık aylığı alan hekimlerin hizmet alım sözleşmesi ile özel sağlık hizmet sunucularında hizmet verip 4/a statüsünde sigortalı olmaları durumunda, tercihlerine bağlı olarak sosyal güvenlik destek primine tabi olacaklar ve haklarında iş kazası ve meslek hastalığı sigortası hükümleri uygulanacaktır. Ancak, hizmet alım sözleşmesine özel bir hüküm konulmadığında 4/a statüsünde sigortalı sayılmayacak olan emekli hekimler 5510 sayılı Kanun'un 30 ve geçici 14. maddeleri uyarınca 4/b

${ }^{20}$ 30/06/2012-28339 RG. 
Özel Sağlık Hizmet Sunucularında Çalışan Hekimlerin Sigortalılığı

statüsünde sigortalı sayılmayacaklardır. Esasen 6663 sayılı Kanundan önceki uygulamasında da 4/b statüsünde sigortalı sayılıp sosyal güvenlik destek primine tabi olanlar hakkında zaten iş kazası ve meslek hastalığı sigortalı hükümleri uygulanmamaktaydı. Bu durumda, hizmet alım sözleşmesi ile özel sağlık hizmet sunucularında hizmet verip 4/a statüsünde sigortalı olarak bildirilmeyen emekli hekimler hakkında iş kazası ve meslek hastalığı sigortası hükümleri uygulanmayacaktır.

Örneğin, özel sağlık hizmet sunucusunda hizmet alım sözleşmesine dayalı olarak çalışan 5510 sayılı Kanun'un ek 10.maddesi kapsamındaki emekli hekimin uğradığı "kaza" iş kazası sayılmayacak, "işin yürütüm şartlarından kaynaklı tutulduğu hastalık" da meslek hastalığg sayılmayacaktır. Dolayısıyla belirtilen sigorta vakalarından ötürü Kurumdan herhangi bir sosyal sigorta yardımı talebinde bulunamayacaktır (Güzel, Okur ve Caniklioğlu, 2020: 603604; Narter ve Şimşek, 2020; Şahin Emir, 2020; Sümer, 2020: 112-132; Bilgili, 2020: 4459)

\section{C- Uzun Vadeli Sigorta Kolları Yönünden}

Özel sağlık hizmet sunucularında 4/a kapsamında sigortalı olarak çalışan hekimler, uzun vadeli sigorta kolları olan malullük ve yaşlılık sigortalarından yararlanmada, ölümleri üzerine geride kalan hak sahiplerinin ölüm sigortasından sağlanan yardımlarından yararlandırılmasında herhangi bir ayrıma tabi tutulmamıştır. Dahası, 4/a kapsamındaki hekimlerin sözkonusu sosyal sigorta yardımlarından yararlanmalarında kanunda aranan prim gün sayıları dışında örneğin "prim borcunun bulunmaması" gibi bir şart da bulunmamaktadır.

5510 sayılı Kanun'un ek 10. maddesi uyarınca özel sağlık hizmet sunucularında 4/b kapsamında sigortalı olarak çalışan hekimler ise uzun vadeli sigorta kolları yönünden de farklı muameleye tabi tutulmuştur. Örneğin, yaşlılık sigortası hükümleri uyarınca aylık bağlanabilmesi için 4/b kapsamındaki hekimlerin 9000 gün malüllük, yaşlılık ve ölüm sigortaları primi bildirilmiş olması şartını yerine getirmeleri getirmektedir. Oysa 4/a kapsamındaki bir hekim için gün sayısı en az 7200 gündür (5510/28.2 md). Benzer biçimde ölüm sigortası kapsamında 4/b kapsamındaki bir hekimin ölümü halinde geride kalan hak sahiplerine ölüm aylığı bağlanabilmesi için en az 1800 gün malullük, yaşlılık ve ölüm sigortaları primi bildirilmiş olması gerekirken, 4/a kapsamındaki bir hekim yönünden her türlü borçlanma süreleri hariç en az 5 yıldan beri sigortalı bulunup, toplam 900 gün malûllük, yaşlılık ve ölüm sigortaları primi bildirilmiş olması yeterli sayılmaktadır (5510/32.2 md).

Özel sağlık hizmet sunucularında 4/b kapsamında sigorta olarak çalışan hekimler ile 4/a kapsamındaki hekimler arasında fiili hizmet süresi zammı bakımından da farklılık bulunmaktadır. 5510 sayılı Kanun'un 40.maddesi uyarınca radyasyona muhatap işlerde çalışan 4/a ve 4/c kapsamındaki sigortalılara, her 360 günleri için 90 gün fiilî hizmet süresi zammı olarak eklenirken, $4 / \mathrm{b}$ kapsamındaki sigortalıların böyle bir hakkı bulunmamaktadır. Örneğin, özel sağlık hizmet sunucusunda radyasyona muhatap işlerde çalışan hekimlerden 4/b kapsamında olanın fiili hizmet süresi zammı hakkı bulunmazken, 4/a kapsaminda olan hekim bu haktan yararlanabilecektir.

Diğer taraftan Sosyal Güvenlik Kurumuna borcu olan 4/b kapsamındaki hekimlerin, uzun vadeli sigorta kollarından sağlanan sosyal sigorta yardımlarından yararlanabilmesi genel sağlık sigortası dahil kendi sigortalılığından dolayı prim ve prime ilişkin her türlü borcunun bulunmamasına bağlıdır (5510/26.2 md; 5510/28.10 md; 5510/32.2 md).

\section{D- Genel Sağlık Sigortası Yönünden}

5510 sayılı Kanun'un ek 10.maddesi kapsamında sağlık hizmet sunucularında 4/b kapsamında sigortalı olarak çalışan hekimlerin Sosyal Güvenlik Kurumu tarafindan finanse 
edilen sağlık hizmetlerinden yararlanmaları bakımından da farklı muameleye tabi tutuldukları söylenebilir. Şöyle ki, 5510 sayılı Kanun'un 60.maddesinin birinci fikrasının (a) bendinin (2) numaralı alt bendine tabi olan genel sağlık sigortalısı (4/b kapsamındakiler) ve bakmakla yükümlü olduğu kişilerin 60 günden fazla prim borçlarının bulunmaması gerekmektedir. Başka bir söyleyişle, 4/b statüsünde sosyal sigortalı olan hekimlerin 30 gün GSS gün sayısı bulunması şartı ile birlikte sağlık hizmeti sunucusuna başvurduğu tarihte 6183 sayılı Amme Alacaklarının Tahsil Usulü Hakkında Kanunun ${ }^{21}$ 48.maddesine göre tecil ve taksitlendirilerek tecil ve taksitlendirmeleri devam edenler hariç 60 günden fazla prim ve prime ilişkin her türlü borcunun bulunmaması, şartı aranmaktadır (5510/67.b md).

4/b kapsamında olanlar dahil bazı genel sağlık sigortalıları açısından "prim ve prime ilişkin her türlü borcunun bulunmaması" şartının, Anayasa ve temel insan hakları belgeleriyle güvence altına alınan sosyal güvenlik hakkı ve kutsal sayılan yaşam hakkı bakımından tartışmalı olduğu belirtilmiştir (Güzel, Okur ve Caniklioğlu, 2020: 815). Bu sebeple olsa gerek, Bakanlar Kurulu ve Cumhurbaşkanlığg kararları ile örneğin, 2018, 2019, 2020 ve 2021 yıllarında 4/b kapsamındaki sigortalılar dahil prim borcu bulunan Türk vatandaşlarının resmi kurumlar tarafından sunulan sağlık hizmetlerinden yararlanabilmeleri için idari düzenlemeler yapılmıştır ${ }^{22}$.

$\mathrm{Bu}$ durumda olan genel sağlık sigortalılarına, prim borçları olsa bile Cumhurbaşkanlığı Kararnamelerinde belirtilen şekilde kamu sağlık hizmetlerinden yararlanabilmeleri imkanı tanınmıştır. Öyle ki, 5510 sayılı Kanun'un ek 10.maddesi uyarınca özel sağlık hizmet sunucularında çalıştırılan ve prim borcu bulunan 4/b statüsünde sigortalı hekimler de kamu sağlık hizmet sunucularından sağlık hizmeti alabilecektir. Belirtelim ki, borcu olan 4/b kapsamındakilerin ilaç giderleri SGK tarafından karşılanmamaktadır.

5510 sayılı Kanun'un ek 10.maddesi kapsamında özel sağlık hizmet sunucularında 4/a kapsamında sigorta olarak bildirilen hekimlerin ise Sosyal Güvenlik Kurumu tarafından finanse edilen sağlık hizmetlerinden yararlanmalarında herhangi bir prim borcu olup olmadığına bakılmaksızın yararlanmaları mümkündür. Kanunda aranan bekleme süresinin geçirilmesi ile sağlı hizmetlerinden yararlanılabilmektedir. Genel sağlık sigortalıları ile bunların bakmakla yükümlü olduğu kimselerin Kurumca finanse edilen sağlık hizmetlerinden yararlanabilmeleri için sağlık hizmeti sunucusuna başvurdukları tarihten önceki son bir yıl içinde toplam 30 gün genel sağlık sigortası prim ödeme gün sayısının olması yeterlidir (5510/67.a md).

\section{E- İşsizlik Sigortası Yönünden}

Kimlerin işsizlik sigortasına tabi olmadıkları 4447 sayılı Kanun'un 46. maddesi üçüncü fikrasında düzenlenmiş, "5510 sayılı Sosyal Sigortalar ve Genel Sağlık Sigortası Kanunu'nun 4'üncü maddesinin birinci fikrasının (b) bendi kapsamında olanları"” kapsamda olmadıkları ifade edilmiştir. Bu sebeple, 5510 sayılı Kanun'un ek 10. maddesi uyarınca özel sağlık hizmet sunucularında 4/b kapsamında çalışan hekimler hakkında işsizlik sigortası hükümleri uygulanmayacaktır. Dolayısıyla, adlarına işsizlik sigortası primi ödenmeyen 4/b kapsamındaki hekimler işsizlik ödeneğinden yararlanamayacakları gibi kısa çalışma ödeneğinden de yararlanamayacaktır. Benzer biçimde, işveren özel sağlık hizmet sunucusunun ödeme aczine düşmesi durumunda üç aylık ödenmeyen ücret alacakları İşsizlik Sigortası Fonu kapsamında oluşturulan Ücret Garanti Fonundan da karşılanmayacaktır.

\footnotetext{
${ }^{21}$ 28/07/1953-8469 RG.

${ }^{22}$ BKK, 14/05/2018- 2018/11769. 23/06/2018-30457 RG.; CBK, 28/03/2019-859. 29/03/2019-30729 RG.; CBK, 07/01/2020-08/01/2020-31002 RG.; CBK, 23/01/2021-31373 RG.
} 
Özel Sağlık Hizmet Sunucularında Çalışan Hekimlerin Sigortalılığı

Özel sağlık hizmet sunucularında hizmet akdi ile çalışan 4/a statüsünde sigortalı hekimler işsizlik sigortasına tabi oldukları için, 4447 sayılı Kanunda düzenlenen tüm sosyal sigorta yardımlarından yararlanabilirler. Örneğin, işsizlik ödeneği alabilecekleri gibi kısa çalışma ödeneğinden de yararlanabilirler. 5510 sayılı Kanun'un ek 10.maddesi uyarınca, hizmet alım sözleșmesi ile özel sağlık hizmet sunucularında hizmet veren hekimler, hizmet alım sözleşmesi metni içerisinde hekim çalışmasının 4/a kapsamında sigortalı olarak bildirilmesine ilişkin özel bir hüküm var ise 4/a kapsamında sigortalı sayılmakla birlikte, hizmet akdine dayalı olarak çalışmadıklarından haklarında işsizlik sigortası hükümleri uygulanmayacaktır (SGK, 2020a). Bu sebeple de 4447 sayılı Kanunda düzenlenen işsizlik ödeneği, kısa çalışma ödeneği gibi yardımlardan yararlanamayacaklardır.

\section{IV- HEKIMLERIN SİGORTALILIK NITELÍKLERININ PRIME ESAS KAZANÇ TUTARLARINA ETKISII}

Özel sağlık hizmet sunucularında görev yapan hekimlerin sigortalılık nitelikleri prime esas kazanç tutarlarını da etkilemektedir. Hizmet akdine dayalı olarak çalışan veya 5510 sayılı Kanun'un ek 10. maddesi uyarınca hizmet alım sözleşmesine dayalı olarak çalışmakla birlikte 4/a statüsünde sigortalı bildirimi kabul edilen hekimlerin prime esas kazançları 5510 sayılı Kanun'un 80.maddesi birinci fikrasının (a) bendine göre tespit edilecektir. Buna göre, prime esas kazançların hesabında; 1) Hak edilen ücretlerin, 2) Prim, ikramiye ve bu nitelikteki her çeşit istihkaktan o ay içinde yapılan ödemelerin ve işverenler tarafindan sigortalılar için özel sağlık sigortalarına ve bireysel emeklilik sistemine ödenen tutarların, 3) İdare veya yargı mercilerince verilen karar gereğince yukarıdaki (1) ve (2) numaralı alt bentlerde belirtilen kazançlar niteliğinde olmak üzere sigortalılara o ay içinde yapılan ödemelerin, brüt toplamı esas alınır (Tuncay ve Ekmekçi, 2019: 175-179; Güzel, Okur ve Caniklioğlu:2020: 235-241). Bu durumda özel sağlık hizmet sunucularında çalışan hekimler için yaptıkları işin niteliğine uygun gerçek kazançları üzerinden prime esas kazanç beyan edilmesi beklenecektir. Bu durumda muhtasar ve prim hizmet beyannamesi gönderilirken, fiilen yapılan işe uygun "meslek kodu" girileceği için hekimler için düşük kazanç, örneğin asgari ücret üzerinden beyanda bulunulamayacağı beklenebilir.

5510 sayılı Kanun'un ek 10.maddesi uyarınca hizmet alım sözleşmesine dayalı olarak çalışan ve 4/b statüsünde sigortalı olan hekimler ise prime esas kazançlarını asgari ücret üzerinden beyan edebilecektir. 5510 sayılı Kanun'un 80.maddesi ikinci fikrasının (a) bendine göre, 4/b kapsamındaki sigortalılar için aylık prime esas kazanç, 5510 sayılı Kanun'un 82. maddesine göre belirlenen prime esas günlük kazanç alt sınırı ile üst sınırı arasında kalmak şartı ile kendileri tarafından beyan edilecek günlük kazancın otuz katıdır. Bu sigortalılar tarafından Kurumca belirlenen sürelerde aylık prime esas kazanç beyan edilir. Beyanda bulunmayan sigortalıların aylık prime esas kazancı, prime esas günlük kazanç alt sınırının otuz katı olarak belirlenir (Güzel, Okur ve Caniklioğlu, 2020: 242; Tuncay ve Ekmekçi, 2019: 186). Yani aylık asgari ücret tutarı. Görüldüğü üzere 5510 sayılı Kanun'un ek 10. maddesi uyarınca 4/b statüsünde sigortalı sayılan hekimler de prime esas günlük kazanç alt sınırı ile üst sınırı arasında kalmak şartı ile diledikleri tutar üzerinden beyanda bulunabilecektir. Yapılan beyana göre de prim ödeyeceklerdir.

Konu emekli hekim istihdamı olunca durum büsbütün değişmektedir. Hizmet alım sözleşmesine dayalı olarak özel sağlık hizmet sunucusunda çalıştırılan emekli hekimler 4/b statüsünde sigortalı sayılmadıklarından sosyal güvenlik destek primi de ödememektedirler.

Çalışma yaşamında daha düşük kazanç beyanında bulunarak düşük prim ödeme eğiliminin varlığından sözedilebilir. Özel sağlık hizmet sunucularında hizmet alım sözleşmesine dayalı olarak çalıştırılan hekimler kural olarak 4/b statüsünde sigortalı sayıldığından, beyan 
edecekleri prime esas kazanç tutarları ödeyecekleri prim tutarlarını da etkileyecektir. Düşük prime esas kazanç beyanında bulunanlar ise ileride daha düşük sosyal sigorta yardımı alabilecektir.

\section{V- HEKIMLERIN SİGORTALILIK STATÜLERININ ÖZEL SAĞLIK HIZMET SUNUCULARININ SORUMLULUKLARINA ETKİSi}

\section{A- 5510 Sayılı Kanun Kapsamında Zararlandırıcı Sigorta Olayları Açısından}

5510 sayılı Kanun'un ek 10.maddesi uyarınca özel sağlık hizmet sunucularında 4/b statüsünde sigortalı olarak çalışan hekimlerin, "uğradıkları iş kazası" veya "tutuldukları meslek hastalığı” sebebiyle, 5510 sayılı Kanun'un 13 ve 14.maddeleri uyarınca kimlerin sorumlu oldukları yönünde yapılan soruşturma sonucunda özel sağlık hizmet sunucusunun sorumlu bulunması durumunda, bu sorumluluk 5510 sayılı Kanun'un 21.maddesi birinci fikrası ile 23.maddesi ikinci fikrası kapsamında "işveren" statüsünde sayılmayacaktır. Zira, şirket ortağı olan veya mesleğini serbest olarak icra eden hekimler ve tıpta uzmanlık mevzuatına göre uzman olan kişiler ile özel sağlık hizmet sunucusu arasındaki iş ilişkisi hizmet alım sözleşmesine dayanmakta olup, özel sağlık hizmet sunucu hekim çalışanın işvereni değildir. Özel sağlık hizmet sunucusunun sorumluluğu ise olsa olsa 5510 sayılı Kanun'un 21.maddesi dördüncü fikrası kapsamındaki "üçüncü kişinin sorumluluğu”" statüsünde değerlendirilebilecektir. Üçüncü kişi ifadesi ile kastedilenler, sigortalının ve işverenin dişında kalan tüm kişilerdir. (Sözer, 2019: 196)

5510 sayılı Kanun'un ek 10.maddesi uyarınca özel sağlık hizmet sunucularında 4/b statüsünde sigortalı olarak çalışan hekimlerin "uğradıkları iş kazası" veya "tutuldukları meslek hastalığı" sebebiyle, sorumluluğuna karar verilen özel sağlık hizmet sunucusu işveren sayılsaydı, 5510 sayılı Kanun'un 21.maddesi birinci fikrası uyarınca hekim sigortaliya bağlanan sürekli iş göremezlik gelirinin başladığı tarihteki ilk peşin sermaye değeri toplamı, sigortalı veya hak sahiplerinin işverenden isteyebilecekleri tutarlarla sinırlı olmak üzere, SGK tarafından işverene ödettirilecekti. Sağlık hizmet sunucusu 5510 sayılı Kanun'un 23.maddesi ikinci fikrası kapsamında sorumlu sayılsaydı, bu defa bağlanan sürekli iş göremezlik gelirinin başladığı tarihteki ilk peşin sermaye değeri tutarı, 21.maddenin birinci fikrasında yazılı sorumluluk halleri aranmaksızın, işverene ayrıca ödettirilecekti.

Özel sağlık hizmet sunucusu “üçüncü kişi” statüsünde sorumlu sayıldığı durumda ise 5510 sayılı Kanun'un 21.maddesi dördüncü fikrası uyarınca, sigortalıya ve hak sahiplerine yapılan veya ileride yapılması gereken ödemeler ile bağlanan gelirin başladığı tarihteki ilk peşin sermaye değerinin yarısı, Sosyal Güvenlik Kurumunca özel sağlik hizmet sunucusuna ödettirilecektir. Öte yandan, özel sağlık hizmet sunucusunun üçüncü kişi olarak uzun vadeli sigorta kolları bakımından da sorumluluğu bulunmaktadır. "Üçüncü bir kişinin kastı nedeniyle malûl ... olan sigortallya veya ölümü halinde hak sahiplerine, bu Kanun uyarınca bağlanacak aylı̆̆ın başladı̆̆ı tarihteki ilk peșin sermaye dĕgerinin yarısı için Kurumca zarara sebep olan üçüncü kişilere rücû edilir” (5510/39.1md).

Öte yandan, özel sağlık hizmet sunucularında 4/b kapsamında çalışan hekimler hakkında, 6331 sayılı Kanun'un 2.maddesinin ikinci fikrası (ç) bendi uyarınca 6331 sayılı Kanun hükümleri de uygulanmayacaktır. 5510 sayılı Kanun'un ek 10.maddesi uyarınca 4/b statüsünde hekim çalıştıran özel sağlık hizmet sunucuları 6331 sayılı Kanuna göre işveren sayılmadıklarından, 4/b statüsündeki hekimlere karşı Kanunda öngörülen iş sağlığı ve iş güvenliğine ilişkin birçok yükümlülügü yerine getirmekten muaf olabilecektir. Zira, özel sağlık hizmet sunucularında 4/b kapsamında çalışan hekimler, çalışan istihdam etmeksizin 
Özel Sağlık Hizmet Sunucularında Çalışan Hekimlerin Sigortalılığı

kendi nam ve hesabına mal ve hizmet üretimi yapmaktadır. Bağımsız çalışanların anılan Kanunun kapsamı dışında tutulmalarının koşulu, yanlarında hiç kimseyi istihdam etmemeleridir (Baycık, 2013). Kendi nam ve hesabına çalışanlar, yanlarında bir kişiyi bile olsa istihdam ettiklerinde işveren olarak 6331 sayılı Kanuna tabi olurlar (Süzek, 2018: 896). Şüphesiz bu durum hekimin ortak olduğu şirket veya mesleğini serbestçe icra ettiği muayenehanesi için sözkonusudur.

Diğer taraftan, 4/a kapsamında sigortalı bildirimleri yapılan hekimlerden ötürü özel sağlık hizmet sunucularının işveren olarak hem 5510 sayılı Kanun hem de 6311 sayılı Kanundaki tüm yükümlülükleri yerine getirmek zorunda olduğunu söyleyebiliriz.

\section{B- 1219 Sayılı Kanun Kapsamında Zorunlu Mesleki Mali Sorumluluk Sigortası Açısından}

1219 sayılı Tababet ve Şuabatı San'atlarının Tarzı İcrasına Dair Kanun'un ek 12.maddesi ile hekimlere tıbbi kötü uygulamalara karşı mesleki malî sorumluluk sigortası yaptırmak zorunluluğu getirilmiştir. Buna göre, kamu sağlık kurum ve kuruluşlarında çalışan tabipler, diş tabipleri ve tıpta uzmanlık mevzuatına göre uzman olanlar, tıbbi kötü uygulama nedeniyle kendilerinden talep edilebilecek zararlar ile kurumlarınca kendilerine yapılacak rüculara karşı sigorta yaptırmak zorundadır. Bu sigorta priminin yarısı kendileri tarafından, diğer yarısı döner sermayesi bulunan kamu kurumlarında döner sermayeden, döner sermayesi bulunmayan kamu kurumlarında ise ilgili kurum bütçelerinden ödenmektedir.

Özel sağlık kurum ve kuruluşlarında çalışan veya mesleklerini serbest olarak icra eden tabip, diş tabibi ve tıpta uzmanlık mevzuatına göre uzman olanlar da, tıbbi kötü uygulama sebebi ile kişilere verebilecekleri zararlar ile bu sebeple kendilerine yapılacak rücuları karşılamak üzere mesleki malî sorumluluk sigortası yaptırmak zorundadır. Zorunlu mesleki malî sorumluluk sigortası, mesleklerini serbest olarak icra edenlerin kendileri, özel sağlık kurum ve kuruluşlarında çalışanlar için ilgili özel sağlık kurum ve kuruluşları tarafından yaptırılır. Özel sağlık kurum ve kuruluşlarında çalışanların sigorta primlerinin yarısı kendileri tarafından, yarısı istihdam edenlerce ödenir. İstihdam edenlerce ilgili sağlık çalıșanı için ödenen sigorta primi, hiçbir isim altında ve hiçbir şekilde çalışanın maaş ve sair malî haklarından kesilemez, buna ilişkin hüküm ihtiva eden sözleşme yapılamaz.

Mesleki zorunlu mali sorumluluk sigortası primlerinin ödenmesi bakımından da hizmet alım sözleşmesine dayalı olarak özel sağlık hizmet sunucularında görev yapan hekimler aleyhine özel sağlık hizmet sunucuları lehine bir sonuç olduğu görülmektedir. Hizmet alım sözleşmesine dayalı olarak özel sağlık hizmet sunucularında görev yapan hekimler, teknik olarak özel sağlık hizmet sunucusunun çalışanı değildir. Hekimlere serbest meslek makbuzu ya da fatura mukabili ödeme yapılmaktadır. Böyle olunca hizmet alım sözleşmesine dayalı olarak özel sağlık hizmet sunucusunda görev yapan hekimlerin zorunlu mali sorumluluk sigortası primleri kendileri tarafından ödenmek durumundadır. Bu sebeple hekimler aleyhine bir sonuç olduğu söylenebilir.

\section{VI- HEKIMLIK HİMET ALIM SÖZLEŞMESI KAPSAMINDA KESILEN FATURALARIN SOSYAL GÜVENLIKK KURUMUNA ÖDETTIRILMESI}

“Sağlık hizmeti sunucuları, Kuruma bildirmiş oldukları hekimlerden sözleşme kapsamı branşlarda fiilen hizmet sunanlar tarafindan verilen sağllk hizmetlerini, Kurumca belirlenen istisnalar hariç olmak üzere ve Kurum mevzuatına uygun olarak fatura edebilirler. Aksi takdirde, bu faturalara ait tutarlar Kurumca karşılanmaz” (5510/46.2 md). Buna göre özel sağlık hizmet sunucusu faturasının SGK tarafından ödenebilmesinin şartı; SGK ile 
sözleşmeli sağlık kurumunda görev yapan SGK'ye bildirimi yapılmış hekim olacak ve hekim fiilen yani bizzat o özel sağlık hizmet sunucusu bünyesinde sunduğu sağlık hizmetini fatura edebilmesidir (Şen, 2015).

Öte yandan, "Kurumla sözleşmeli özel sağllk hizmeti sunucuları tarafindan Kuruma bildirilen hekimlerden Kurumca belirlenen yüzdelik oran içerisinde kalan ve sözleşme kapsamı branşlarda fiilen hizmet sunan sağllk hizmet sunucusu bünyesindeki hekimlerle sinırlı olmak üzere,

a) Il Sağlık Müdürlüklerinden çalışma izni almak suretiyle ve 1219 sayılı Tababet ve Şuabatı San'atlarının Tarzı İcrasına Dair Kanuna aykırı olmayacak şekilde sözleşme ile çalıştırmış oldukları hekimlerden aynı zamanda fatura karşılı̆̆ hizmet alımı yaparak,

b) Bir iş sözleşmesine tabi olmamakla birlikte, İ Sağllk Müdürlüklerinden çalışma izni almak suretiyle ve 1219 sayıl Kanuna aykırı olmayacak şekilde hekimlerden fatura karşıllı̆̆ hizmet alımı yaparak,

genel sağlık sigortası kapsamındaki kişilere vermiş oldukları sağlık hizmetlerini Kurumca belirlenmiş usul ve esaslara uygun olarak fatura etmeleri hâlinde, verilmiş olan sağllk hizmetlerinin bedeli Kurum tarafindan karşllanır"'(5510/Ek 10.1 md). Hekimlerin sigortalılık statülerinin Kuruma fatura edilen bedellerin Kurumca ödenmesi açısından etkili olmadığı görülmektedir.

\section{SONUÇ}

5510 sayılı Kanun'un ek 10.maddesi ikinci fikrası uyarınca, şirket ortağı olan veya mesleğini serbest olarak icra eden hekimler ile tıpta uzmanlık mevzuatına göre uzman olan kişilerin, hizmet alım sözleşmesi ile özel hukuk kişileri ve/veya vakıf üniversitelerine ait sağlık kurum ve kuruluşları bünyesinde hizmet vermeleri halinde, hizmet alım sözleşmelerinde aksine bir hüküm bulunmadığı sürece, 23/04/2015 tarihinden itibaren geçerli olmak üzere 4/b kapsamında sigortalı sayılmışlardır. Düzenleme ile hizmet alım sözleşmesinde hekimlerin 4/a kapsamında sigortalı olarak bildirilmesi kararlaştırılmış ise 4/a statüsünde sigortalı bildirimleri esas alınacak, aksi halde zorunlu olarak 4/b kapsamında sigortalı oldukları kabul edilecektir. Bu durum bir kişide aynı anda 4/a ve 4/b statülerinin çakışması durumunda 4/a statüsüne öncelik tanıyan ilkeden farkl1lık göstermektedir.

Özel sağlık hizmet sunucularında çalışan 4/b kapsamındaki hekimler ile 4/a kapsamında çalışanlar arasında sosyal güvenlik hakları açısından da farklılıklar bulunmaktadır. Örneğin, 4/b kapsamındaki bir hekim hastalık sigortası hükümlerinden yararlanamayacaktır. Benzer biçimde, şirket ortağı olan 4/b kapsamındaki hekimler analık sigortası hükümlerinden de yararlanamayacaktır. Yaşılılık aylığı alan hekimler ise 4/a statüsünde sigortalı sayılmadıklarında sosyal güvenlik destek primine tabi olmadıkları için iş kazası ve meslek hastalığı sigortası hükümleri de uygulanmayacaktır.

Uzun vadeli sigorta kollarından yaşlılık sigortası hükümleri uyarınca aylık bağlanabilmesi için 4/a kapsamındaki bir hekim için 7200 gün sayısı yeterliyken, 4/b kapsamındaki bir hekim için 9000 gün sayısı aranacaktır. Ölüm sigortasından geride kalan hak sahiplerine aylık bağlanmasında 4/a kapsamındakiler için borçlanma süreleri hariç en az 900 gün sayısı yeterliyken, 4/b kapsamındakiler için en az 1800 gün gerekmektedir. Fiili hizmet süresi zammından yararlanma açısından da 4/b kapsamındaki hekimler hak kaybı yaşamaktadır. Örneğin, radyasyona muhatap işlerde çalışan 4/a kapsamındaki bir hekim her 360 günü için 90 gün fiili hizmet süresi kazanırken, 4/b kapsamındaki bir hekimin fiili hizmet süresi zammı hakkı bulunmamaktadır. 
Özel Sağlık Hizmet Sunucularında Çalışan Hekimlerin Sigortalılığ1

Genel Sağlık Sigortası kapsamında Sosyal Güvenlik Kurumu tarafından finanse edilen sağlık hizmetlerinden yararlanma açısından da değişiklikler bulunmaktadır. Özel sağlık hizmet sunucusunda çalışan 4/b kapsamındaki bir hekimin sağlık hizmetlerinden yararlanabilmesi için diğer şartların yanı sıra sağlık tesisine başvurduğu tarihten geriye doğru bir yıl içinde 60 günden fazla prim borcu bulunmaması gerekmektedir. Aksi halde, kendisinin fiilen çalıştı̆g 1 özel sağlık hizmet sunucusunda, kendi ürettiği sağlık hizmetinden bile resmi olarak yararlanmayacaktır. Oysa, 4/a kapsamındakiler için otuz günlük genel sağlık sigortası prim gün sayısının bulunması yeterlidir.

Özel sağlık hizmet sunucusunda çalışan 4/b kapsamındaki hekimin kısa ve uzun vadeli sigorta kollarından sağlanan sosyal sigorta yardımlarından yararlanabilmesi için Sosyal Güvenlik Kurumuna kendi sigortalılığından dolayı, Genel Sağlık Sigortası dahil prim ve prime ilişkin her türlü borçlarının ödenmiş olması zorunludur. 4/a kapsamındakiler için hizmet bildirimi yeterli olup, işverenleri tarafından primlerinin yasal süresinde ödenip ödenmemesi sosyal sigorta yardımlarından yararlanabilmeleri için belirleyici değildir.

Öte yandan özel sağlık hizmet sunucuları 4/b kapsamında hekim çalıştırdıkları ölçüde bu çalışma ilişkisinde avantajlı bir duruma gelmiştir. En başta, 4/b kapsamındaki hekimler kendi sigorta primlerini kendileri ödeyecektir. Özel sağlık hizmet sunucusunun prim ödeme yükümlülüğü olmayacaktır. 4/b kapsamındaki hekimlerden radyasyona muhatap işlerde çalışanlar fiili hizmet süresi zammından yararlanmadıkları için ilave sigorta primi ödenmesi de gerekmeyecektir. Özel sağlık hizmet sunucusu 4/b kapsamındaki hekimler açısından "işveren” sayılmadığı için, 4/b statüsündeki hekimin uğradığı iş kazası ya da tutulduğu meslek hastalığını Sosyal Güvenlik Kurumuna yasal süresinde bildirme yükümlülüğünden muaf olacaktır. Bu yükümlülük 4/b kapsamındaki hekimin üzerinde kalacaktır.

Hizmet alım sözleşmesine dayalı olarak özel sağlık hizmet sunucularında 4/b statüsünde sigortalı olarak görev yapan hekimler dilerler ise aylık asgari ücret üzerinden dahi sigorta primi ödeyebileceklerdir. Ticari ya da serbest meslek kazançlarının çok altında sigorta prim matrahı beyan edebilirler. 4/a statüsünde sigortalı olan hekimler adına sigorta prim matrahı bildiriminde gerçek kazançlarının altında beyanda bulunulması ise yaptıkları işin niteliği ve meslek kodları dikkate alındığında Sosyal Güvenlik Kurumu tarafından yapılan risk değerlendirmelerinde inceleme sebebi olabilecektir.

4/b kapsamındaki hekimlerin uğradıkları iş kazası ya da tutuldukları meslek hatalığında, yapılan soruşturmalarda özel sağlık hizmet sunucusunun sorumluluğuna kanaat getirildiğinde bu sorumluluk "işverenin sorumluluğu” kapsamında değil ama "üçüncü kişinin sorumluluğu” kapsamında ele alınacaktır. Şöyle ki, özel sağlık hizmet sunucusu işveren sayıldığı durumlarda sigortalıya bağlanan sürekli iş göremezlik gelirinin başladığı tarihteki ilk peşin sermaye değerinin toplamı Sosyal Güvenlik Kurumu tarafindan ödettirilmektedir. Özel sağlık hizmet sunucusu üçüncü kişi sayıldığı durumlarda ise sigortalıya ve hak sahiplerine yapılan veya ileride yapılması gereken ödemeler ile bağlanan gelirin başladığı tarihteki ilk peşin sermaye değerinin yarısı, Sosyal Güvenlik Kurumunca ödettirilecektir. Aynı durum malullük ve ölüm sigortasında da geçerli olacaktır. Özel sağlık hizmet sunucusunun sorumlu sayıldığı durumlarda, üçüncü kişi olarak 4/b kapsamındaki hekime veya hak sahiplerine malullük ya da ölüm aylığı bağlanması durumunda aylığın başladığı tarihteki ilk peşin sermaye değerinin yarısı Kurum tarafından ödettirilecektir. 


\section{Kaynakça}

Alper, Y. (2019). Sosyal Sigortalar Hukuku. Bursa: Dora Yayinları.

Aydınlı, İ. (1998). İş Hukukunda Butlan (Geçersizlik)'ın Uygulanmasına İlişkin Yargıtay Kararı İncelemesi. Çimento İşveren. 12(2). (Erişim: 01 Ocak 2020).

Bal Bektaş, Ö. (2014). İşsizlik Sigortası. (Yayınlanmamış Doktora Tezi). Ankara Üniversitesi Sosyal Bilimler Enstitüsü.

Baycık, G. (2013). Çalışanların İş Sağlığı ve Güvenliğine İlişkin Haklarında Yeni Düzenlemeler. Ankara Barosu Dergisi. 2013/3.103-170.

Bilgili, Ö. (2009). Özel Să̆lık İşletmelerinde Personel İstihdamı. İzmir: İzmir Tabip Odas Yayın1.

Bilgili. Ö. (2020). Yeni Koronavirüs (COVID19) İş Kazası Sayılır Mı? III. Sosyal Bilimlerde Kritik Tartışmalar Kongresi Tam Metin Bildiriler Kitabi. 2020.

Bozdemir, E. (2018). Özel Hastanelerde Hekimlik Hizmet Alımı Uygulamasının Mali Açıdan Analizi. Konuralp Tip Dergisi. 12(1). 87-96.

Çelik, N., Caniklioğlu, N. ve Canbolat, T. (2019). İs Hukuku Dersleri. İstanbul: Beta Yayınları.

Ekin, A. (2016). Zorunlu Sigortal1lık İlkesi Kapsamında Sigortalılık Hallerinin Çakışması ile Gelir ve Aylıkların Birleşmesi. Sosyal Güvenlik Dergisi. 6(1). 94-125.

Ekmekçi, Ö. ve Yiğit, E. (2020). Bireysel $\dot{I}_{\text {Ş }}$ Hukuku Dersleri. İstanbul: Onikilevha Yayınları.

Ermumcu, S. (2009). 5510 Sayılı Kanun Bakımından Sigortalılık Hallerinin Çakışması. Dokuz Eylül Üniversitesi Hukuk Fakültesi Dergisi. 11(1). 89-111.

Eyrenci, Ö., Taşkent, S. ve Ulucan, D. (2019). Bireysel İş Hukuku. İstanbul: Beta Yayınları.

Güzel, A., Okur, A. R. ve Caniklioğlu, N. (2020). Sosyal Güvenlik Hukuku. İstanbul: Beta Yayınları.

Karaman, M. H. (2014). 5510 Sayll Kanun'da Tanıml Sosyal Sigorta Statüleri ve Çakışan Sigortalılık İlişkisi. MÜHF-HAD (özel SayıProf. Dr. Ali Riza Okur'a Armağan). 20(1). 875893.
Kayık, A. (2015). Sosyal Güvenlik Hukukunda Sigortalılık Hallerinin Çakışması. Terazi Hukuk Dergisi. 10(106). 27-32.

Narter, S.ve Şimşek, C. (2020). Sağlık Çalışanları İçin Covid-19 Hastalığı İş Kazası veya Meslek Hastalığı Mıdır? Karatahta/Işs Yazıları Dergisi. 16. 139-170.

SB. (2019). Sağlık Bakanlığı Sağlık Hizmetleri Genel Müdürlüğünün 31/05/2019 tarihli ve 2019/10 say1l Genelgesi.

SB. (2020). Sağlık Bakanlığı Sağlık Hizmetleri Genel Müdürlügünün 21/04/2020 tarih ve 54718026 sayılı talimatı.

SGK (2013). Sosyal Güvenlik Kurumu Emeklilik Hizmetleri Genel Müdürlüğünün 22/02/2013 tarihli ve 2013/11 sayılı Genelgesi.

SGK (2015a). Sosyal Güvenlik Kurumu Sigorta Primleri Genel Müdürlüğünün 11/11/2015 tarihli ve 2015/25 say1l Genelgesi.

SGK (2015b). Sosyal Güvenlik Kurumu Emeklilik Hizmetleri Genel Müdürlüğünün 03/07/2015 tarihli ve 2015/19 sayılı Genelgesi.

SGK (2016a). Sosyal Güvenlik Kurumu Emeklilik Hizmetleri Genel Müdürlüğünün 29/09/2016 tarihli ve 2016/21 say1l Genelgesi.

SGK (2016b). Sosyal Güvenlik Kurumu Emeklilik Hizmetleri Genel Müdürlüğünün 24/05/2016 tarihli ve 2964528 sayılı Genel Yazis1.

SGK (2020a). Sosyal Güvenlik Kurumu Emeklilik Hizmetleri Genel Müdürlüğünün 18/06/2020 tarihli ve 2020/20 say1l Genelgesi.

SGK (2020b). Sosyal Güvenlik Kurumu Emeklilik Hizmetleri Genel Müdürlüğünün 01/09/2020 tarihli ve 10300024 say1l Genel Yazis1.

Sözer, A. N. (2019). Türk Sosyal Sigortalar Hukuku. İstanbul: Beta Yayınları.

Süzek, S. (2018). İş Hukuku. İstanbul: Beta Yayınları.

Şakar, M. (2017). Sosyal Sigortalar Uygulaması. İstanbul: Beta Yayınları.

Şahin Emir, A. (2020). İşçinin Yakalandiğ 1 Bulaşıc1 Hastalığın 5510 Sayılı Kanun Anlamında İş Kazası Olup Olmadığının Değerlendirilmesi-Domuz Gribi (H1N1) ve Koronavirüs (COVID-19) Özelinde Bir Değerlendirme. Legal İş Hukuku ve Sosyal Güvenlik Hukuku Dergisi. 17(66). 547-592. 
Özel Sağlık Hizmet Sunucularında Çalışan Hekimlerin Sigortalılığ1

Sümer, H. H. (2020). İşçinin İşyerinde Yakalandığı COVID-19 Hastalığı İș Kazası Mıdır? Selçuk Hukuk Kongresi 2020 Özel Hukuk Tebliğleri Tam Metin Kitabı. Nobel Yayınları. 2020. 112-132.

Şen, F. (2015). Özel Sağlık Kurumlarında Hekimlik Hizmet Alımı-Hekimlerin Fatura Karşılığı Çalıştııılması Analizi. [http://www. fezasen.com/dosyalar/ozel_saglik_kurumlarind a_hekim_calisma_usulleri_analizi.pdf].

(Erişim: 10 Ekim 2020).

Tuncay, A. C. ve Ekmekçi, Ö. (2019). Sosyal Güvenlik Hukuku Dersleri. İstanbul: Beta Yayınları.

Uşan, F. (2016). Kanun Yapmak Bu Kadar Kolay Mi, Yahut Bu Kadar Zor Mu? (5510 Say1l Kanun Uygulaması Çerçevesinde Bir Tespit). YBHD. 2016/1. 09-228 
